\title{
The Socio-economic Effectiveness \\ of Funding for the Motor Roads Network Skeleton Formation in the Region
}

\author{
Mikhail B. Dvinskiy*, VIadislav N. Rutskiy, \\ Elena N. Pochekutova \\ and Alexander M. Bulavchuk \\ Siberian Federal University \\ 79 Svobodny, Krasnoyarsk, 660041, Russia
}

Received 25.01.2016, received in revised form 14.02.2016, accepted 16.06.2016

The article describes dependence and influence of the roads maintenance and financing indicators on social and economic development of the region. Today Russia is experiencing an active phase in the process of social and economic automobilization. The Krasnoyarsk Territory is one of the leaders among other regions on the number of cars per capita, and Krasnoyarsk takes the second place in this rating among the country's cities. The small business development, increasing number of private cars per population and vast territorial length make the motor roads a crucial factor in the socio-economic development of this region. The estimation of economic losses for the Krasnoyarsk Krai caused by the basic roads network underdevelopment and the influence of expected budget reductions on this process are presented as the final conclusion.

Keywords: roads network skeleton, economic losses, socio-economic development, value of statistical life.

This paper was written under financial support in the framework of the RFH Grant №15-12-24007 a (p) "The Methodological Approaches to the Formation of the Applied Models for Analysis and Forecasting of the Resource Regions of Russia Economy in the Terms of Spatial Inequality and Asymmetry (on the Example of the Krasnoyarsk Territory)"

DOI: 10.17516/1997-1370-2016-9-8-1916-1928.

Research area: economics.

\section{Research objective}

Within the modern conditions of development against the backdrop of negative processes in the international economy and decline in prices on hydrocarbons Russia has faced a deterioration of the budget system indicators: the growth in expenditures under the income contraction. In the beginning of $2000 \mathrm{~s}$, the Federal Budget surplus was followed by a deficit; the regional budgets indicators (shortage rate) were even worse. Having been quite a healthy federal entity in the sense of budget, for the period 2008 - 2015 the Krasnoyarsk Territory had to increase the public debt from

(c) Siberian Federal University. All rights reserved

* Corresponding author E-mail address: mike11.80@mail.ru 
1,5 billion rubles (for the end of 2008) to 92 billion rubles (as at 1 April, 2016). This process has been contributed also by a faster growth in social expenditures, which recently have amounted to $80 \%$ of the regional budget. Such dynamics is explained by the growth of social security indicators within the ambition for carrying out the May Presidential Decrees and social requirements. As a result, the tendency in recent years has been towards austerity across the budget expenditures on other activities.

Over the period 2010 - 2014 Russia intensively performed the activities on social facilities network streamlining. This source of the budget costs saving has almost exhausted itself. The further reduction in this network is no longer possible. The pension reform (i.e. cuts in expenditures on the pension support) cannot be implemented in the short or medium term. The institutions of public authority have now focused on other potential sources for the budget costs saving.

Since there is almost no other expenditure commitments beyond the social costs, options are not so many. The Krasnoyarsk Territory, as well as the whole Russia, is expected to encounter a decline in expenditures on the infrastructure projects, and, unfortunately, on the road facilities. The purpose of this research is to assess a possible socio-economic impact on the Krasnoyarsk Territory caused by the decreased budgetary financing on the roads construction and maintaining.

\section{A brief comparative analysis \\ of the road infrastructure development in Russia and the world}

The total length of roads in Russia is 1396 ths. $\mathrm{km}$ (fifth in the world), but the qualitative indicators are significantly lower: the length of highways is $929 \mathrm{~km}$ (thirty fifth in the world). On the number of automobiles Russia is ranked $5^{\text {th }}$ in the world and $1^{\text {st }}$ in Europe.

As of today, the longest highways network has been formed in China (111 $950 \mathrm{~km}$ ) and in the USA (77 $017 \mathrm{~km})$. China is an absolute world leader in rates and volumes of the expressways construction (annual rates of construction are measured by more than 7 ths. $\mathrm{km}$ ). In this context one can emerge the following trends: the major global economies coincide with countries having the longest highway length (China and the USA); the country with the most longstanding growth rate and the one with the same indicator for the

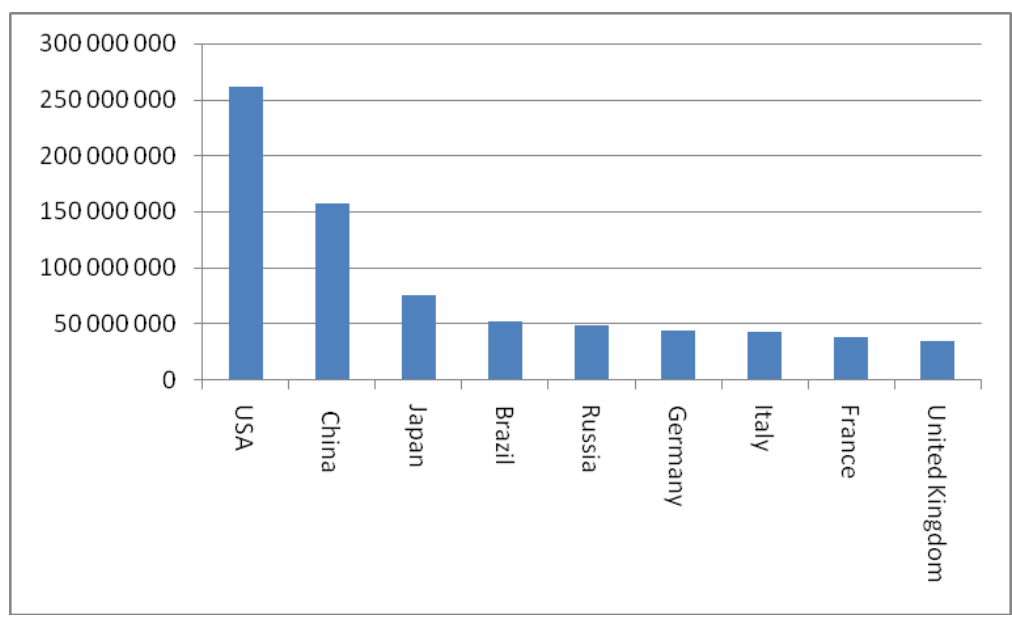

Fig. 1. Number of cars across the countries (items) 
basic expressways network (highways) also converge (China).

It's interesting to make a comparison on how much the budgets of different countries spend on the road infrastructure financing. In modulus, within the international comparisons of 2008, Russia had the road budget of approximately US\$ 11 billion, the USA - a little less than US\$ 130 billion; Japan - $€ 53$ billion; France and Germany - US\$ 20 - 21 billion; China - US\$ 17 - 25 billion (according to different figures); Canada - US\$12. Per one resident of the country these indicators are as follows: the USA - US $\$ 427$, Japan - US\$ 417, Canada - US\$ 352, France US\$ 334, Germany - US\$ 268; Russia - US\$76 and China-US\$ 14.

\section{Vehicles per capita ratio in the Russian regions (cars per 1000 inhabitants) for the period 1970 - 2014}

The main growth of automobilization in Russia's regions occurred over the period of 1991 - 2010. At that time, the number of cars per population as to 1985 doubled (Fig.2). As a consequence, the transport issues of regions and cities dramatically exacerbated.

We shall note, that the number of cars in the Krasnoyarsk Territory per 1000 inhabitants increased from 131, 4 items in 2003 to 263 items in 2014. For the Russian Federation this indicator was, thus, 153 items in 2003 and 257 items in 2014. Obviously, the rates of growth in the number of cars per population in this region are above the Russian average one (Fig. 3).

The most visible effect of the outrunning increase in automobilization towards the transport infrastructure development was observed in the major cities and capital of the Krai. In the period 2000 - 2014 Krasnoyarsk was characterized by a strong growth in civil autimobilization. As in 2014 Krasnoyarsk took the $2^{\text {nd }}$ place in Russia on the number of cars per 1000 inhabitants (the leading place was given to Vladivostok).

At this time, according to the statistics and surveys, the road transport causes $37 \%$ of air emissions in Krasnoyarsk, provided that one ride
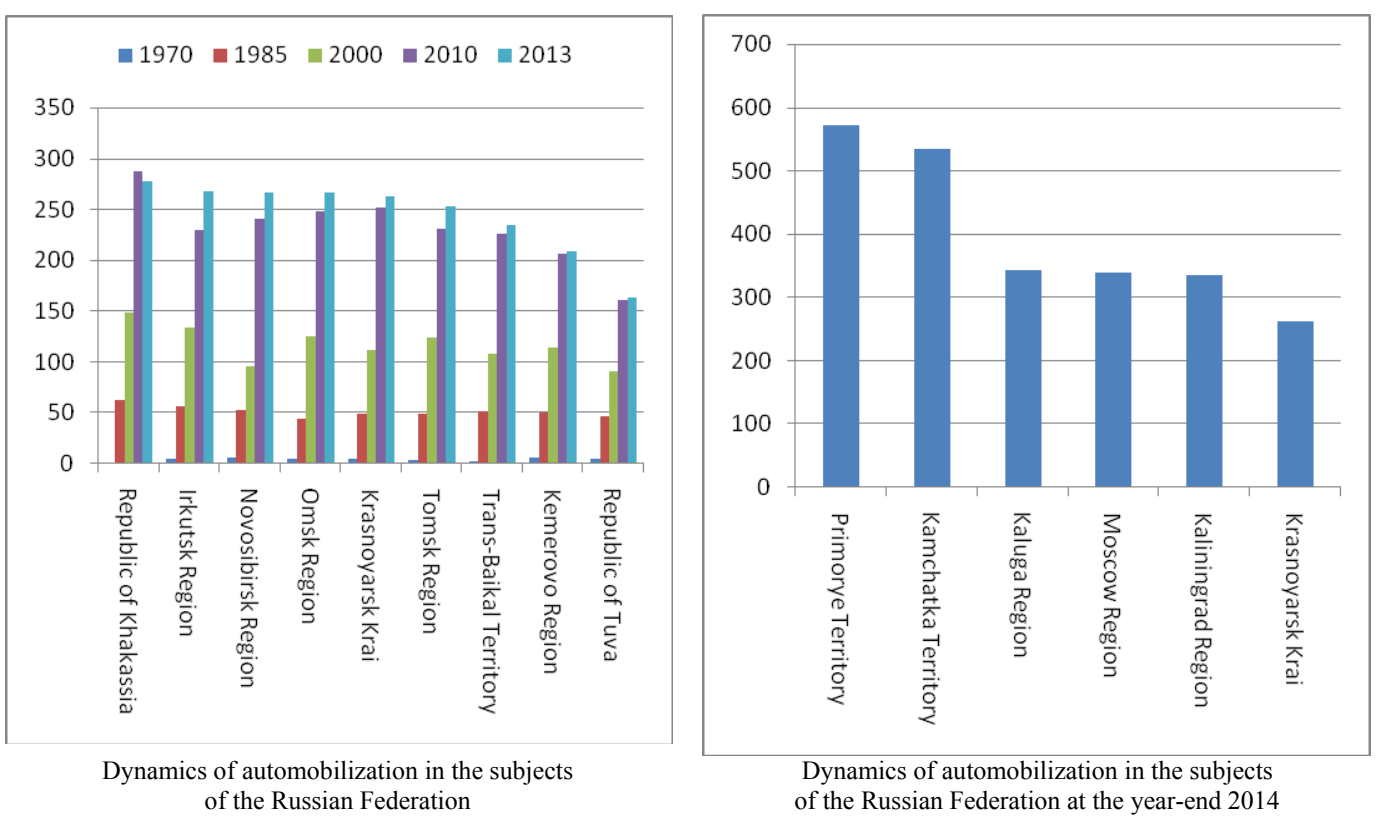

Fig. 2. Overview on the dynamics of automobilization in the subjects of the Russian Federation 


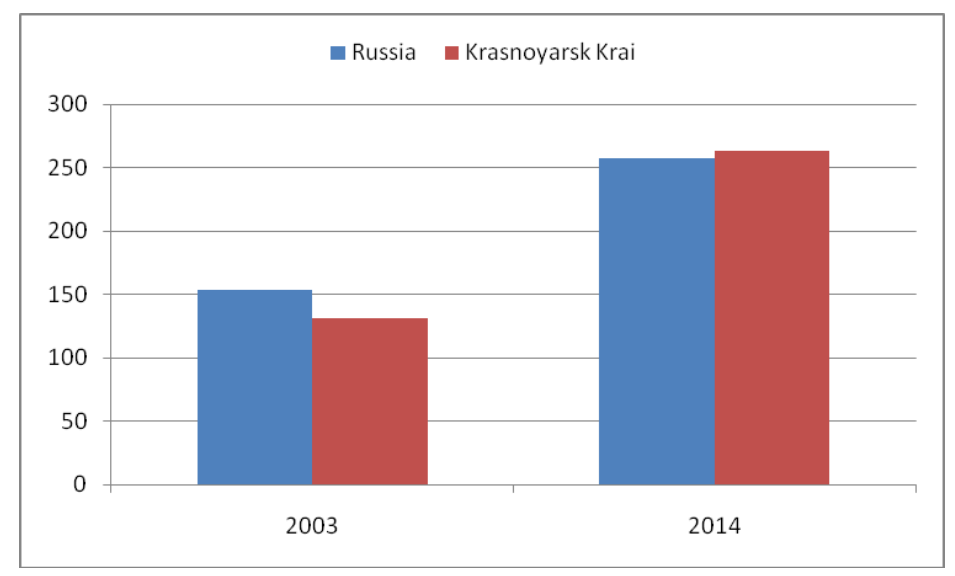

Fig. 3. Comparative analysis of the number of cars per population (in items per 1000 inhabitants)

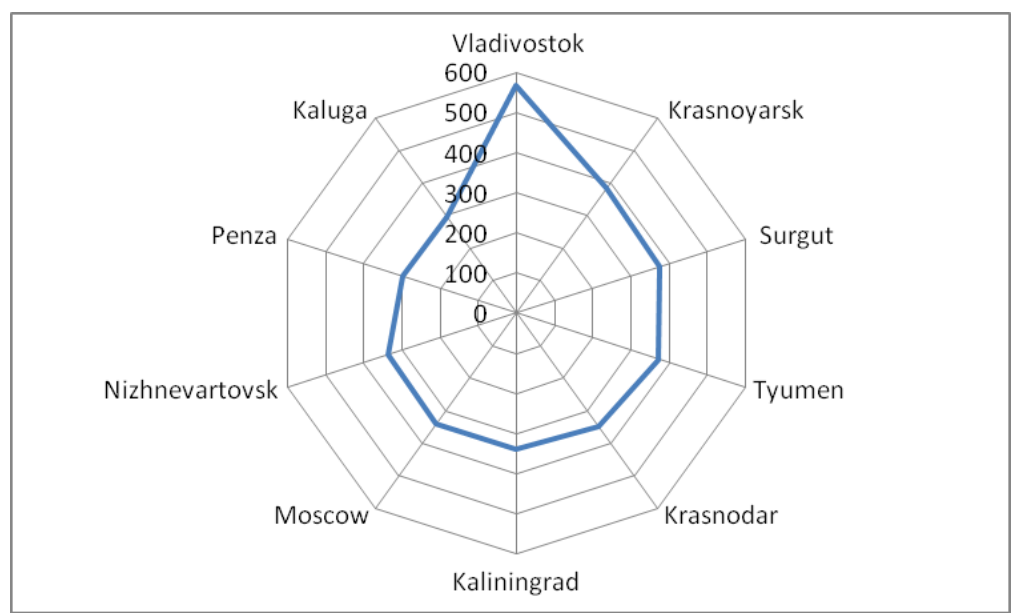

Fig. 4. Number of cars per 1000 inhabitants in Top-10 Russian cities

takes 40 minutes at the recommended $20-30$ minutes.

\section{Comparative studies on the roads} development and assessment

\section{of potential economic losses (benefits)} for the Krasnoyarsk Krai

In early 2015 the road length in the Krasnoyarsk Krai was 31 826, 2 km, of which 1 151, $5 \mathrm{~km}$ are federal roads, 13 927, $9 \mathrm{~km}$ represented by the regional roads and 16746,8 $\mathrm{km}$ - by the secondary ones.

According to the type of surfacing, the roads have the following structure (by the data for early
2014): 5 550, $9 \mathrm{~km}(38,8 \%)$ of roads are topped with the enhanced type of surfacing; $8084 \mathrm{~km}$ $(56,6 \%)$ - with the transitional type of road surface and $661 \mathrm{~km}(4,6 \%)$ are the earth roads.

The length of local roads (a street-road network of urban districts, localities and rural settlements) is $14149 \mathrm{~km}$. Expert estimates claim that only $3 \%$ of them are properly registered and have the entitling documents (as at 1 January, 2013), which can cause a considerable statistic error in measurements.

Due to the geographical position and climatic conditions of the Krasnoyarsk Territory, there is a network of seasonable hard-roads with 
a total length of more than 9 ths. $\mathrm{km}$, of them: $2908,3 \mathrm{~km}$ are the regional roads and 6335,5 $\mathrm{km}$ are the local ones (i.e. the roads which are mainly located in the territory of Yeniseisk, SeveroYeniseisk, Evenki and Taymyr (DolganoNenetskiy) municipal districts).

The roads network's density in the Krasnoyarsk Krai is 6, $04 \mathrm{~km} / 1000$ square $\mathrm{km}$ (by this measure the region has been ranked only ${79^{\text {th }}}^{\text {in }}$ the Russian Federation), that can also be driven by a high proportion of sparsely-populated and hard-to-reach areas.

Assessment of potential economic losses

(benefits) for the Krasnoyarsk Krai

by the small business development

indicator

Within the Soviet period, the transport development in the Siberian territories was notable for a clear predominance of the railroad transport. In this region the largest enterprises were focused on the raw materials supply and export of the final products by railway. As a consequence, in this region the basic roads network was not formed.

Let's practice on this region the mentioned world tendency to closeness between the indicators of basic roads network development and economy. For this purpose we've formed and analyzed some spatial data sets, and also counted paired and multiple coefficients of correlation for the road network density and key indicators of the economic development (GRP, GRP per capita, nominal wages, number of small business entities per 10000 inhabitants, turnovers of small enterprises within a decade). The results were the following: under- and overdevelopment of the roads network across the federal entities is characterized by the low level of correlation with the abovementioned economic indicators. Indeed, the reason for this has been outlined before: a significant percentage of the Russian economic potential transports its product by railways or pipelines.
Nevertheless, Western economics argues that there is a crucial tie between the territory-wide infrastructural development (roads takes one of the most important positions) and economy. Thus, further, we have calculated indicators, which mark not quantitative, but qualitative development of the regional economy: in particular, the revenue of small enterprises per employed person in this sector, since the given process started to develop only within the transitional period and was not planned before the reforms. The results of comparison between the Krasnoyarsk Territory and the all-Russian and district indicators are shown below (Fig.5).

There is a clear leadership on crucial quantitative indicators of the economic development and, at the same time, significant weaknesses in turnovers of small enterprises per one employee (in fact, labor productivity). Certainly, the reliance on rise in labor productivity (i.e. increase in the number highlyefficient workplaces) constitutes a key goal for the economic growth in Russia stated in the relevant May Presidential Decree.

In this case, the coefficients of correlation calculated for the federal districts and entities are 0,52 and 0,43 correspondingly, that marks the essential relation between these indicators. Thus, in the context of small business development one can maintain that the basic roads network underdevelopment (particularly, in the central and partially in the northern and southern areas of the Krai) prevents from the turnover indexes improving, labor productivity enhancing and, as a consequence, competitiveness increasing. Such conclusion determines repeated statements on the fact that the Krasnoyarsk Territory has a high untapped potential in the production and other economic sectors, including the sphere of small business development through servicing and using products made by the regional primary industries. 


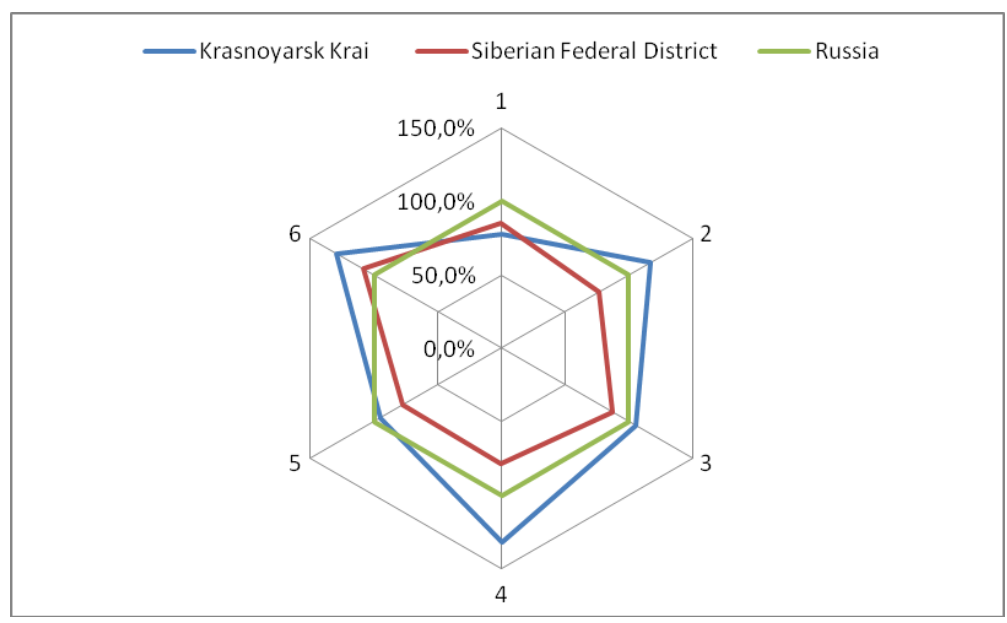

Fig. 5. Deviation of the small business development index and macroeconomic fundamentals from the average Russian indicators (Russia 100\%): 1 - Turnover of small enterprises per employee; 2 - GDP (GRP) per capita; 3 - Average monthly wage; 4 - Volume of shipped goods by manufacturing units per capita; 5 - Retail turnover per capita; 6 - Number of small enterprises per 10000 inhabitants

The assessment of potential economic losses of the Krasnoyarsk Krai caused by the road network underdevelopment (the roads' density and state) has been carried out through the straight-lined method (the estimation is aimed not at an absolute precision, which is literally impossible in this context, but at possible range delimitation):

- gapping with the average development indexes for the roads network in the Siberian Federal district determines potential economic losses on the small business enterprises' turnover as 39,2 billion rubles annually (3, $1 \%$ of GRP);

- gapping with the average development indexes for the road network in the Russian Federation determines potential economic losses on the small business enterprises' turnover as 123, 2 billion rubles annually (9,8 \% of GRP);

\section{Assessment of economic losses (benefits) the Krasnoyarsk Krai influenced \\ by the "Road-safety" factor}

An imbalance in the processes of automobilization and transport infrastructure in the Krasnoyarsk Krai most acutely were felt in the sphere of road safety. On the accident indicators and injury rates this region is considered as dangerous. As official statistics of 2015 reported, the Krasnoyarsk Teritory was marked by 4473 road accidents which resulted in 567 deaths. These figures ranked the region as the $5^{\text {th }}$ in Russia and the $1^{\text {st }}$ in the Siberian Federal District! At the same time, it is also specific that $48 \%$ of accidents occurred in areas with poor conditions for the road maintenance.

This conclusion is also proved by the official statistics on municipalities: the percentage of inadequate local public roads length within the total local public roads length is $\mathbf{3 2 , 8 \%}$ !

The period of 2011 - 2013 was marked by the growth in number of accidents (by $4,8 \%$ ) and injuries (by 6,8\%), while reducing the death rate (by 3,6\%). In 2014 and 2015 there was a positive tendency in accidents: by 2014 the rate reduced by $6,5 \%$. Such dynamics also has another meaning apart from the driving safety: in the context of upsurge in costs for OSAGO (compulsory motor third party insurance) the road accidents with minor damages are increasingly not registered. 
Following the statistics from January to November 2015 on the absolute crash rate the Krasnoyarsk Krai took the $1^{\text {st }}$ place in the Siberian Federal District and the $6^{\text {th }}$ in Russia. The first five positions were taken only by Moscow, the Moscow Region, SaintPetersburg, the Krasnodarsk Krai, Nizhnii Novgorod Region, Rostov Region and the Republic of Tatarstan, i.e. by the regions with larger population, traditionally high standard of living as well as high number of private transport.

Over the abovementioned period, on the number injured people per 100000 inhabitants the Krasnoyarsk Krai was ranked the $\mathbf{7}^{\text {th }}$ in Russia and the $\mathbf{1}^{\text {st }}$ in the Siberian Federal District (Fig.6). On the absolute deaths rate the region was on the $5^{\text {th }}$ place in Russia and on the $1^{\text {st }}$ in the District.

In general, in 2014 the dynamics of road crashes in the Krasnoyarsk Krai was disappointing: the crash rate index exceeded the average Russian mark by $20,5 \%$, and the number of peopled injured in car accidents per 100000 inhabitants was $26,9 \%$ higher than the national average (Fig.7).

At the same time, one particularly welcome fact is a positive tendency that has been observed within the last decade: the decline in mortality and traffic injuries against the backdrop of increasing number of the road accidents.

Expansionofthistendencywasnamelycaused by two factors: the health sector development and changes in the rules for statistical monitoring of traffic accidents. In particular, since 2010 the death toll caused by car crashes includes people both killed on impact and succumbed to their injuries within 30 days after the crash (before 2017 this period was 7 days).

Thus, the data comparison on road-traffic deaths with a view to 100000 inhabitants for 2003 and 2015 is not entirely correct, since it was based on different statistical approaches (Fig. 8). In fact, for 2015 the value of this indicator calculated according to the previous practices is considerably lower.

In any case, the relationship between the number of cars per population, road crashes and accidents rate is evident: if the first indicator increases, theotherones, though disproportionally, but also will increase.

The most significant economic losses from inadequate financing in the road construction and maintenance are obvious from the statistics on the road traffic injuries. Below we provide the

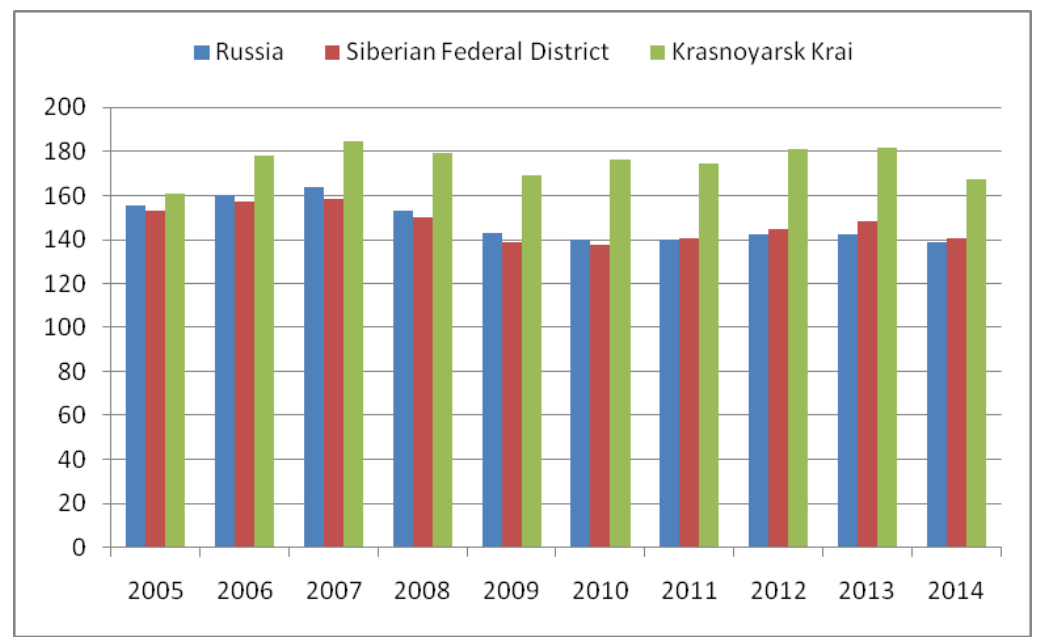

Fig. 6. Crash rate per 100000 inhabitants (number of accidents) 


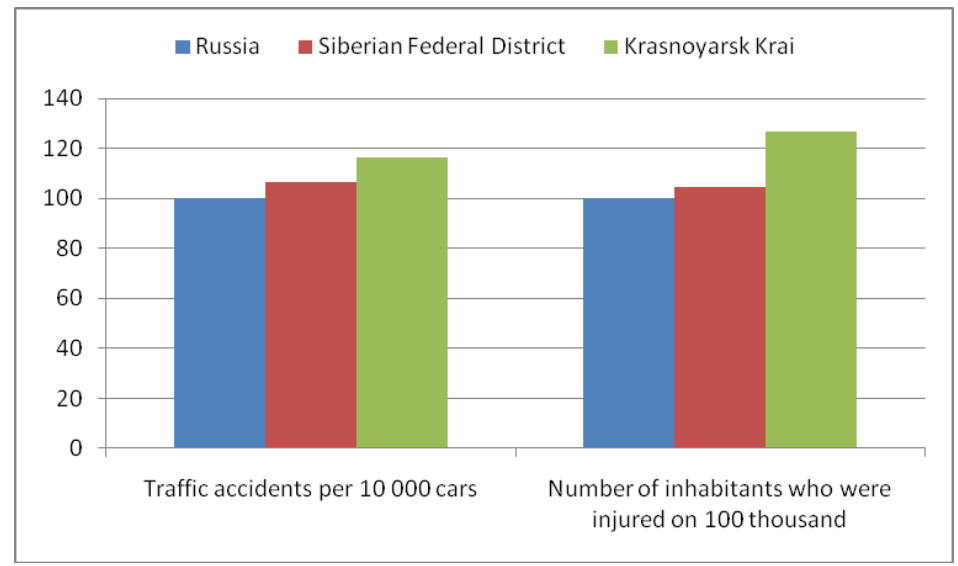

Fig. 7. Ratio of the road safety indexes to the national average values (Russia $-100 \%$ )

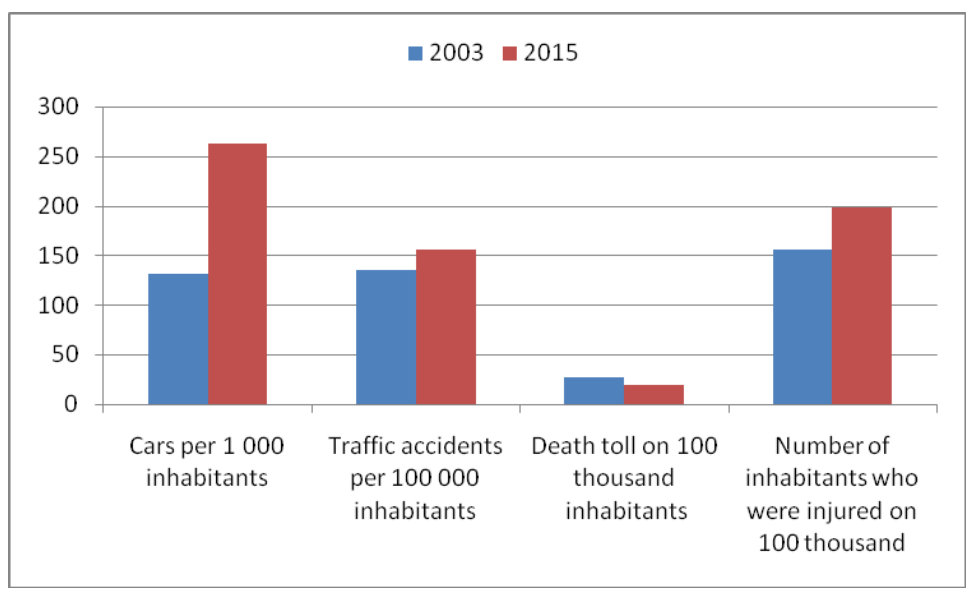

Fig. 8. Comparison between changes in the number of cars per population and traffic accidents dynamics with injured and killed people

valuation only for a statistical life suffered by the Krasnoyarsk Krai within the period of 2010 2015.

The authors share the opinion on how precious the life is. Since so, all the calculations made below are solely simulated and shown from a scientific perspective.

The practice of statistical life estimation in Russia differs from the one in Europe: today the human life in Russia is estimated at 4,5 million rubles (following to the recommendations of the Statistical Centre of "Rosgosstrakh"), while the European Commission suggests estimating at 3,1 million euros (226,3 million rubles).
Of course, if we include the national experience into these calculations, then the economic losses can be compared with the size of annual fiscal savings, but even in this case, during the reported period the Krasnoyarsk Territory lost more than 16 billion rubles in the cost for statistical life.

According to the figures obtained following the European Commission's recommendations, this number is 800 billion rubles, or $54 \%$ of the annual GRP of the Krasnoyarsk Krai.

In 2004 Vladimir Putin, the President of the Russian Federation, declared an interesting objective of the economic development: "Doubling 


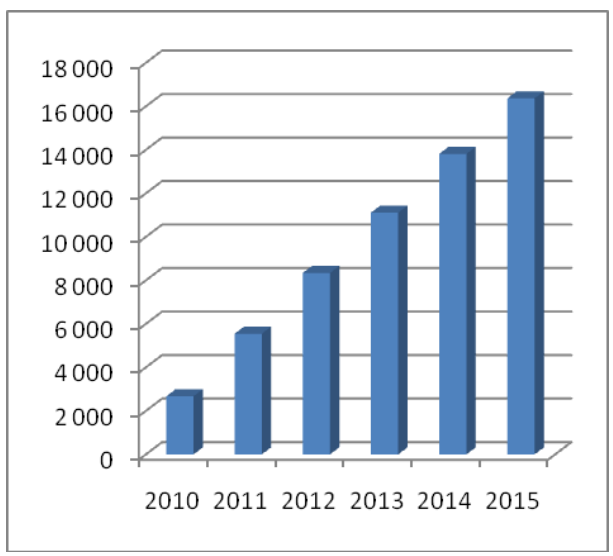

Recommendations by the Statistical Centre of "Rosgosstrakh" for Russia

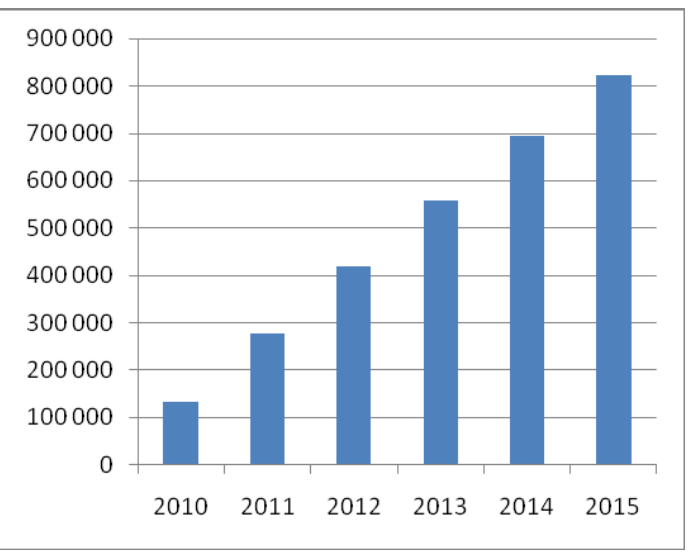

Recommendations by the European Commission

Fig. 9. Estimation of economic losses on value of statistical life (million rubles)

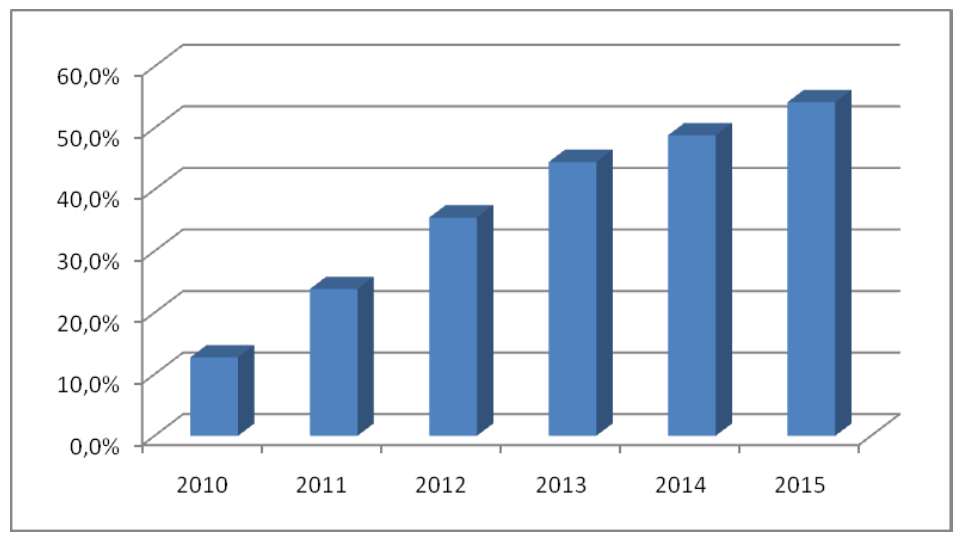

Fig. 10. Ratio of economic losses on value of statistical life for the period $2010-2015$ to the annual GRP (on a cumulative basis); the value of statistical life is calculated on the basis of EC's recommendations

GDP by 2010" (from the values of 2003, i.e. within the period of 8 years). If we translated this objective on the Krasnoyarsk Krai, then it would be "lost" on the roads simply through the value of statistical life.

The infrastructure peculiarities described above demonstrate that the road network of the Krasnoyarsk Region requires expansion, and the current roads are in need of significant investments in their reconstruction and reconditioning. At the present time this region lacks major road engineering projects, except for the completing construction of the access roads to the $4^{\text {th }}$ bridge over the Yenisei in Krasnoyarsk. The total investment in this project is 13 983,3 million rubles, i.e. $36,9 \%$ of the overall funding received within the program "Roads of Krasnoyarsk for the period $2014-2016$ ".

\section{Why does the Krasnoyarsk Krai need the roads network skeleton?}

As scientists and analysts claim, the difficulty of determining how the transport infrastructure development influences on the economic indexes lies in a wide lag between investments and feedbacks. Among the current 
studies on this problem, the work by D. Aushauer receives a particular attention. Its importance involves the length of time analysis, which covers several decades (what is impossible for timeseries in Russia). This very research contains the time-series analysis of the gross-output, private investments, labor costs and state investments in the infrastructure within 40 years. As a result, the following statistical link has been determined: 1 per cent-increased investments in the road construction provides a capital productivity growth in the private sector by $0,3 \%-0,5 \%$ [Aschauer, 1989].

Let's apply these results to the development indicators of 2014 for the Krasnoyarsk Krai. $1 \%$-increased budget expenditures on the road facilities, particularly concerning the construction of new roads, would amount some to 141 million rubles. In this case, the effect can be measured by enhancement of the following figures: GRP by 427-711 billion rubles; the amount of fixed funds brought into operation by 798-1 330 million rubles; the tax liabilities level by 359-599 million rubles. Undoubtedly, these efficiency calculations cannot be obtained with a short-term or even middle-term period. Nevertheless, the calculations demonstrate that 1 ruble of non-recurring additional investments in the roads development can annually provide at least 2,5 rubles of the tax and non-tax revenue.

The construction of roads aimed at solving the problem of territorial separation, i.e. in other words, those roads which connect regions and cities with each other, highly likely produce many positive external effects. It is indicated by the demand on the construction materials and labor force along the whole road. Taking into consideration the Krasnoyarsk Region's geographical position, this demand is mainly covered by the local production of construction materials due to a great importance of the transport leg for manufactures working in the neighbor federal entities. Bringing the roads into service guarantees the market expansion for enterprises of the production sector and agricultural producers of different ownership types and scales; improvement of the labor market efficiency resulted by broaden job opportunities and increased competition (both from on the part of employees and employers); development of agglomerations and agglomeration effects; increase in the landresources involvement into the economic cycle; and availability of the agro-processing centers for private farms.

As for the Krasnoyarsk Krai, building a road network skeleton will lead to an increase in "Engel 'coefficient" (Golts ${ }^{2}$ coefficient), which measures the density of road network including the actual population and settlements density). It's interesting to note that earlier these coefficients were calculated concerning the length of all transport routes (motor roads, air-, river and railways). The Krasnoyarsk Krai has in this case a very high indicator for the air transport length that also allows increasing of the coefficients' common value. Since, as it has been defined before, in the modern conditions for economic development namely the motor roads start to play a key role, we will calculate the coefficients only for the roads with solid and enhanced types of surfacing.

Increasing in values of these coefficients will allow the Krasnoyarsk Krai to cope with disadvantages across the territory arrangement peculiar to almost all the Eastern regions of this country. The specific feature of this territory, population and production forces organization in Siberia and the Far East regions is their vast areas and a low level of population density, production forces and infrastructure. Thus, an absence of the road network skeleton can be expressed in the following negative elements: 
Table 1. Comparison of Engel and Golts coefficients for the major entities in the Siberian Federal District

\begin{tabular}{|l|c|c|c|c|}
\hline $\begin{array}{c}\text { Entity of the } \\
\text { Russian Federation }\end{array}$ & $\begin{array}{c}\text { Engel coefficient for } \\
\text { the roads with solid } \\
\text { type of surfacing }\end{array}$ & $\begin{array}{c}\text { Engel coefficient для for } \\
\text { the roads with enhanced } \\
\text { type of surfacing }\end{array}$ & $\begin{array}{c}\text { Golts coefficient for } \\
\text { the roads with solid } \\
\text { type of surfacing }\end{array}$ & $\begin{array}{c}\text { Golts coefficient для for } \\
\text { the roads with enhanced } \\
\text { type of surfacing }\end{array}$ \\
\hline Omsk Region & 0,83 & 0,71 & 0,95 & 0,82 \\
\hline Novosibirsk Region & 0,88 & 0,40 & 2,13 & 0,97 \\
\hline Krasnoyarsk Krai & 0,33 & 0,15 & 0,75 & 0,33 \\
\hline Irkutsk Region & 0,54 & 0,21 & 1,26 & 0,48 \\
\hline Russia & 0,66 & 0,41 & 0,64 & 0,40 \\
\hline
\end{tabular}

1) One settlement can be connected with the other, but they both are separated from the basic roads system;

2) The traffic connection between two settlements often can be several times longer than the map distance;

3) A settlement has no traffic connection with any other settlement.

It should be noted that the mentioned characteristics have been found not only in the North and Far North areas, but also in central, southern, western and eastern territory of the Krasnoyarsk Krai. The lack of improved transport connection between the settlements results in the out-migration of working-age population that, in its turn, poses serious problems for the further development of territories, which have lost their labor resources. The enterprises performing in these settlements are not able to expand their activities, and, as a rule, they only struggle for the market survival (difficulties and high transport costs, limited labor resources, low-skilled and non-experienced workforce in the location).

The Krasnoyarsk Krai has 576 municipalities (settlements), among which only 44 are urban districts and settlements and the other $\mathbf{4 8 8}$ are rural settlements (up to date data). The idea to close rural settlements will inevitably reduce the developed land area of the Krai and its economic potential. Here we'll cite some data taken from the population census of 2010: the number of settlements (rural settlements) devoid of inhabitants is 91 .

Draft socio-economic development strategy for the Kranoyarsk Krai until 2030

The draft socio-economic development strategy for the Krasnoyarsk Krai until 2030 includes the following positions to develop the road facilities: "Development of the Krai's territory through the basic network of federal roads, which forms the main transport corridors and provides interregional links"; "development of the road infrastructure in new neighborhoods"; "alignment of the technical condition of regional and intermunicipal motor roads with the requirements"; "development and modernization of the intra-urban and intra-settlement roads mainly on the territory of Krasnoyarsk agglomeration".

The first measure can be considered as an idea to form the roads network skeleton through the federal budget. Still, in this case, one should understand that the Russian Federation has its own plans on the roads development, which includes two motor roads belonging to the Krasnoyarsk Krai, i.e. the Russian routes M53 "Baikal" and M54 "Yenisei". Of course, these very highways should be considered as a ground for the network skeleton, but they cannot be seen as the "network" per se. Still, there are no other large-scale projects on the federal roads construction within the real plans (with the 


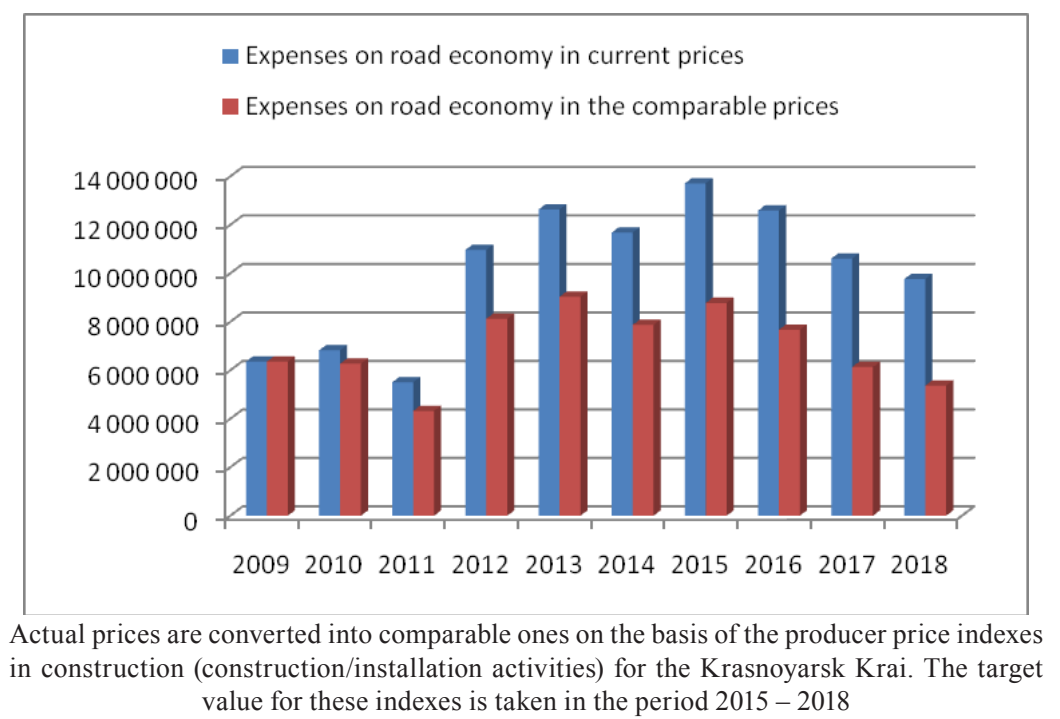

Fig. 11. Expenditures on the road facilities on the basis of actual and comparable prices of 2009 (th. rubles)

approved funding and construction period). That is why in the problem of roads network skeleton development in the Krasnoyarsk Territory one should count on their own efforts. This outlined brief description of the content for this field comes down to the reconstruction of two federal motor roads mentioned above and does not include new roads construction (except for the roads around Achinsk and Kansk). Unfortunately, it all suggests that there is no detailed plans on the basic roads network construction for the Krasnoyarsk Krai until 2030.

\section{Assessments of need for the budgetary financing in recovering from economic losses caused by the roads network underdevelopment}

Fig. 11 shows tendencies in the Krai's budget expenditures on the road facilities in actual and comparable prices made over a decade (from 2009 to 2018). Orienting on the budget expenditures figures planned for the road facilities, by 2018 the Krasnoyarsk Krai would remain at the level of 2009-financing in comparable prices (or even a little lower). The highest financing indicators in actual prices occurred in 2015. In order to fix this level of budget expenditures given the rising prices in this industry, one should correct the budget costs planned for the road facilities within the following variations: $+14 \%$ in 2016 ; $+43 \%$ in 2017 and $+64 \%$ in 2018 .

In absolute figures, these comparisons are as follows: the planned budget costs for 2016, 2017 and 2018 are 12,6 billion rubles, 10,6 billion rubles and 9,8 billion rubles; reasonable costs aimed at saving the comparable financing level of 2012 - 2015 are 14,4 billion rubles, 15,2 billion rubles and 16,0 billion rubles correspondingly. The reported amounts vary widely and in 3 planning years the gap between them will be 12,6 billion rubles (underfunding of the road facilities). At the same time, the projects on reconstruction, maintenance, modernization and construction of roads are actually valid. Thus, in the near future, the work quality issues and the problems of accident rates caused by the poor roads maintenance will have a particular relevance. 
Ernst Engel, a German statistician and economist, famous for the Engel curve and the Engel's law (born in 1821 - died in 1896).

2 Grigorii A. Golts, Institute for National Economic Forecasts, the RAS.

\title{
References
}

Aschauer, D.A. (1989). Is Public Expenditure Productive?, In Journal of Monetary Economics, 23, 177-200.

Gorchakov, Ia. L. (2002). Assessing the Transportation Network of East Siberian Economic Region, In Bulletin of Irkutsk State Academy of Economics, 4.

\section{Социально-экономическая эффективность финансирования создания опорного каркаса сети автодорог региона}

\author{
М.Б. Двинский, В.Н. Руцкий, \\ Е.Н. Почекутова, А.М. Булавчук \\ Сибирский федеральный университет \\ Россия, 660041, Красноярск, пр. Свободный, 79
}

Статья рассматривает зависимость и влияние показателей состояния и финансирования автомобильных дорог на социально-экономическое развитие региона. Сегодня Россия переживает активную фазу автомобилизации своего общества и экономики. Красноярский край является одним из лидеров среди регионов по количество автомобилей на душу населения, а город Красноярск занимает в данном рейтинге второе место среди городов страны. Развитие малого бизнеса, растущая обеспеченность населения личным автотранспортом, огромная протяженность территории делают автодороги ключевым фактором в сочиально-экономическом развитии региона. Конечным результатом является оченка экономических потерь Красноярского края в результате отставания в развитии опорной сети автодорог и влияние ожидаемого сокращения бюджетного финансирования на данный прощесс.

Ключевые слова: опорный каркас сети автодорог, экономические потери, социальноэкономическое развитие, стоимость среднестатистической жизни.

Грант РГНФ № 15-12-24007 а (р) «Методологические подходы к формированию прикладных моделей анализа и прогнозирования экономики ресурсных регионов России в условиях пространственного неравенства и асимметрии (на примере Красноярского края)».

Научная специальность: 08.00.00 - экономические науки. 